\title{
Persepsi Dan Pengambilan Keputusan Milenial Terhadap Instrumen Investasi Masa Depan
}

\author{
Received: \\ 29 Oktober 2020 \\ Revision \\ Yosua Stevanus* dan Dedi Rianto Rahadi \\ Jurusan Manajemen, Universitas President, Indonesia
}

received:

24 November

2020

Accepted:

5 Desember

2020

\begin{abstract}
:
This study aims to look at the perceptions and decision making taken by millennials in choosing instruments to invest in planning future finances and to provide an understanding and explanation of current instruments or forms of investment that are more practical to use. Technology and human thinking are increasingly advanced along with the rapid and dynamic development of the times, many new investment instruments that are more modern and apply digital media for research using qualitative approach through interviews of 40 respondents. Findings from research shows that many millennial generations are developing with low-risk media such as: gold, deposits, property, and mutual funds. Results show that respondents have investments in the form of 35\% deposits, 30\% property, $20 \%$ mutual funds and $15 \%$ shares.
\end{abstract}

Keywords: perception, millennial, investment

\begin{abstract}
Abstrak:
Penelitian ini bertujuan untuk mengetahui persepsi dan pengambilan keputusan yang diambil oleh kaum milenial dalam memilih instrument-intrumen yang digunakan dalam investasi untuk merencnakan keuangan di masa mendatang dan memberikan pemahaman serta penjelasan mengenai Instrumen atau bentuk-bentuk dari investasi saat ini yang lebih praktis untuk digunakan. Teknologi dan pemikiran manusia semakin maju seiring dengan perkembangan zaman yang cepat dan dinamis banyak instrumen investasi baru yang bermunculan yang lebih modern dan mengadopsi media digital pada penelitian ini menggunakan pendekatan kualitatif melalui wawancara terhadap 40 responden. Penelitian mendapatkan hasil bahwa banyak kaum milenial yang berinvestasi dengan media yang memiliki resiko yang rendah seperti emas, deposito, properti dan reksadana. Presentase yang didapat dari hasil penelitian berupa deposito sebesar $35 \%$, properti 30\%, reksadana $20 \%$, dan saham sebesar $15 \%$.
\end{abstract}

Kata kunci: persepsi, milenial, investasi

\section{Pendahuluan}

Dengan adanya era modern saat ini banyak sekali platform yang ada saat ini yang dapat digunakan sebagai media investasi baik jangka panjang dan jangka pandek baik minim resiko, moderat sampai dengan resiko yang paling tinggi, dengan merancang rencana investasi sejak masa dini milenial dapat meminimalisir resiko-resiko keuangan yang akan terjadi dimasa yang akan datang seperti krisis finansial, kebutuhan akan dana yang besar dengan waktu yang singkat, sakit, dan lain-lain. Semakin pesatnya perkembangan teknologi ada banyak cara untuk berinvsetasi dengan baik secara konvensiaonal dan modern sekalipun baik resiko rendah sampai yang panling tinggi sekalipun Bursa Efek Indonesia sebagai lembaga penyelengara perdagangan bursa efek di Indonesia menunjukan 
bahwa Indonesia memiliki hasil return paling tinggi dibandingkan bursa lain di kawasan Asia Tengara dan bursa besar yang ada di dunia (IDX, 2016).

Menurut McLuhan (1962) "inovasi dalam bidang teknologi informasi atau teknologi komunikasi memberi perubahan yang sangat besar terhadap kehidupan masyarakat". Hal yang mengkhawatirkan mengenai investasi saat ini seperti fluktuasi harga, gejolak nilai tukar valuta asing yang tidak stabil, serta oknum-oknum manajer investasi (penyedia jasa investasi atau pialang) yang diatur dalam Pasal 1 Angka 11 UU Pasar Modal (OJK) yang berbunyi "manajer investasi adalah pihak yang kegiatan usahanya mengelola portofolio efek untuk para nasabah atau mengelola portofolio investasi kolektif untuk sekelompok nasabah, kecuali perusahaan asuransi, dana pensiun, dan bank yang melakukan sendiri kegiatan usahanya berdasarkan peraturan perundang-undangan yang berlaku". Hal ini banyak disalahgunakan sejumlah pihak seperti penasihat investasi yang menjadi manajer investasi yang ramai dibicarakan belakangan ini yang menyebabkan klien nya merugi. Hal tersebut meyebabkan banyak kaum milenial takut atau bahkan menjauhkan investasi digital tersebut dan lebih memilih untuk mengalokasikan dana nya ke media investasi lainnya seperti properti, franchise (waralaba resmi), deposito, membeli barang tersier atau branded untuk investasi, atau lebih memilih menabungkan uang nya ke bank. Mereka melakukannya untuk meminimalisir kerugian dalam berinvestasi karena nilainya yang cenderung stabil dan meningkat dari tahun ketahun walau keuntungan yang didapat tidak sebesar investasi baik di saham atau trading forex.

Mengenai hal tersebut pemerintah melalui IDX (Bursa Efek Indonesia) selaku badan penyedia Investasi serta Bank Inonesia dan OJK yang berbadan hukum selaku pihak yang melakukan kegiatan pengawasan terhadap investasi yang terjadi di Indonesia dengan mengeluarkan peraturan Undang Undang Nomor 8 Tahun 1995 mengenai pasar modal. Pasal 3 mengenai fungsi pengawasan pada peraturan tersebut dapat meyakinkan persepsi dan ketertarikan kaum milenial pada investasi yang handal, terpercaya serta terbuka/transparan untuk masa yang akan datang. Banyak persepsi yang terbentuk dibenak investor milenial megenai sektor sektor investasi yang ada. Menurut Alvara Research Center (2017), berdasarkan hasil riset terdahulu yang dilakukan pada kaum milenial menunjukan bahwa kaum milenial sebagian besar berinvestasi pada media investasi yaitu emas sebesar $29.6 \%$, properti $16.7 \%$ asuransi $5.65 \%$.

Berdasarkan uraian diatas maka permasalahan yang dikemukakan yaitu bagaimana persepsi dan resiko yang akan dihadapi milenial terhadap investasi masa depan serta apa saja kelebihan dan kekurangan atas jenis - jenis investasi dalam strategi investasi era milenial. Menurut Kaidah (2015) hasil penelitian yang dilakukan di FEB Universitas Islam Negeri Raden Intan Lampung menunjukan bahwa banyak faktor yang mempengaruhi minat untuk berinvestasi seperti umur, persepsi, status sosial, tingkat pendidikan, tingkat kemapanan, trust level dan profesi. Berdasarkan riset yang dilakukan Inside ID, Andreas Christian (2018) terhadap instrumen investasi yang diminati di Indonesia menunjukan bahwa emas masih menjadi pilihan masyarakat sebab setengah dari responden memiliki investasi berupa emas. Investasi lain yang dimiliki masyarakat adalah deposito sebesar 37\%, properti $30 \%$, reksadana $22 \%$, dan saham sebesar $17 \%$. Hasil riset Inside ID menunjukan bahwa kaum pria cenderung lebih besar dalam melakukan investasi dari pada kaum perempuan serta kelompok usia yang melakukan investasi berdasarkan hasil riset partisipasi pada investasi adalah 31-45 tahun. Dari data atas penelitan dan analisis terdahulu dapat disimpulkan bahwa sebagian besar milenial berinvestasi pada investasi yang memiliki resiko yang rendah serta nilainya yang cenderung stabil dan meningkat di setiap tahunnya.

\section{Kajian Literatur}

\section{Persepsi}

Persepsi adalah pola pikir yang terbentuk akibat rangsangan yang diterima oleh panca indra baik itu melihat, merasakan, mencium, mendengar, dan mencucipi sebagai rangsangan akibat faktor lingkungan. Secara sedarhana persepsi dapat dikatakan sebagai peristiwa yang pernah dialami dan saling berhubungan yang didapatkan dengan mengaitkan beberapa informasi dan menafsirkan pesan. Listiani (2018) mendeskripsikan bahwa persepsi merupakan "kesan yang diperoleh oleh individu melalui panca indera kemudian di analisa (diorganisir), diintepretasi dan kemudian dievaluasi, 
sehingga individu tersebut memperoleh makna". Menurut Rahadi \& Susilowati (2019) "persepsi adalah proses dimana individu mengatur dan menafsirkan kesan indrawi mereka untuk memberi makna pada lingkungan mereka".

\section{Pengambilan Keputusan}

Pengambilan Keputusan adalah suatu menentukan pilihan yang harus diambil dalam suatu masalah atau pristiwa yang ada. Menurut Rahadi \& Susilowati (2019) "pengambilan keputusan atau decision making adalah kegiatan untuk menilai atau menentukan pilihan yang daimbil dari beberapa perhitungan dan alternatif yang ada".

\section{Milenial}

Milenial adalah generasi yang lahir andata rentang tahun 1980 - 2000 atau disebut juga dengan generasi Y (Gen-Y) yang aktif pada media sosial dan digital masa kini. Menurut Yoris (2016) dalam bukunya yang berjudul "Generasi Langgas Millenials Indonesia" milenial di Indonesia dapat terbagi menjadi 3 kelompok besar yakni: pertama, the students millenials yang lahir pada tahun 1993 hingga 2000; kedua, the working millenials yang lahir pada 1987 sampai 1993, pada tahun 2015 kelompok ini berusia 22 sampai 28 tahun; dan yang ketiga, the family millenials, yaitu mereka yang sudah mulai berkeluarga atau mulai memikirkan ke arah tersebut.

\section{Investasi}

Menurut Tandio (2016) investasi sebenarnya adalah semua kegiatan memanfaatkan waktu, uang atau tenaga dengan harapan mendapatkan keuntungan dan manfaat di masa kemudian hari. Invsetasi adalah kegiatan membeli saat ini dengan mengharapkan nilai yang tinggi di masa mendatang selisih antara harga pembelian awal dan penjaulan dapat dijawaikan keuntungan. Investasi juga ada banyak bentuk dan jenis berikut ini bentuk - bentuk investasi terkini:

\section{Investasi Emas (Logam Mulia)}

Menurut Fauziah, (2016) logam mulia adalah salah satu contoh investasi yang cenderung konsisten meningkat dari tahun ketahun sehingga dapat memberikan keuntungan bagi pemilik dalam investasi ini terdapat 2 jenis yang pertama emas fisik yang kita dapat memakai benda tersebut seperti cincin, kalung dan lain-lain yang cenderung turun jika dijual dari harga pembelian awal dikarenakan kadar emas yang terkandung dapat berkurang, serta kita juga harus menyediakan tempat yang aman untuk menyimpannya kedua yakni emas online atau masyarakat lebih familiar dengan emas Antam (Aneka tambang Tbk) atau emas Pegadaian keuntungan dari media ini adalah transaksi yang mudah karena hanya melalui handphone pemilik, alokasi dana yang mudah, tersimpan aman tanpa safe deposit box.

\section{Investasi Pasar Modal (Saham)}

Menurut Hidayat, Muktiadji, Supriadi (2019) saham adalah jenis investasi berupa investasi digital dan berbentuk portfolio perusahaan yang bertujuan untuk mendapatkan keuntungan, saham biasanya telah terdaftar di bursa efek indonesia sehingga siapapun dapat membeli saham tersebut dengan miniamal pembelian 1LOT atau 100 lembar saham dengan syarat mempunyai rekening bank skuritas serta wajib ada NPWP (Nomor Pokok Wajib Pajak), dengan berinvestasi saham kita mengharapkan keuntungan dari fluktuasi harga saham atau kenaikan harga saham (Capital Gain) dan memiliki peluang untuk mendapatkan deviden yang dibagikan kepada pemegang saham perushaan jika perusahaan mendapatkan laba pada periode tersebut.

\section{Investasi Obligasi (Pemerintah/Korporasi)}

Menurut Dewi, Purbawangsa, Abundanti (2016) obligasi adalah investasi berbentuk surat utang baik surat yakni berisikan penjanjian untuk melunasi pokok utang pada waktu yang telah ditentukan dan disepakati serta membayar imbalan berupa kupon/bunga kepada penerbit efek obligasi atau surat utang dibagi menjadi 2 bentuk yaitu surat utang korporasi/perusahaan Contoh: IDX (2020) "Bank BRI Obligasi Berkelanjutan III Bank BRI Tahap I Tahun 2019 Seri A dengan kode Emiten BBRI dan tanggal jatuh tempo 17 November 2020". Rating idAAA maupun surat berharga 
pemerintah/negara Contoh :IDX (2020) "Obligasi Negara Th.2006 Seri FR0034 dengan nilai yang bersedar sebesar 15.729.400.000.000 dan tanggal jatuh tempo pada 15 Juni 2021" yang dapat diperjualbelikan. Obligasi juga memiliki jangka waktu yakni jangka menengah atau jangka panjang, investasi ini merupakan salah satu dalam elemen media investasi dengan resiko moderat atau menengah tapi dengan bunga yang lebih besar dari pada pasar uang dan deposito bank namun lebih kecil dari pendapatan deviden yang diterima pemegang saham.

\section{Investasi Properti}

Menurut Munawaroh (2017) investasi properti merupakan investasi idaman semua orang termasuk kaum milenial yang belum berkeluarga maupun sudeh berkeluarga, investasi dalam bentuk ini biasaya memiliki jangka waktu yang Panjang dan memiliki fisik dan nilainya pertahun cenderung meningkat dan stabil serta investasi ini juga dapat dijadikan passive income bagi pemilik properti seperti sewa kontrakan, kos-kosan, dan sewa lahan, investasi dalam bentuk ini bisa berupa : rumah/hunian, gudang, ruko, apartement, tanah, sawah, perkebunan, dan lain-lain akan tetapi untuk properti berupa apartemen pemilik hanya berhak atas bangunan karena sesuai dengan peraturan pemerintah.

\section{Investasi Forex Online Tranding}

Merupakan salah satu media investasi yang bergerak secara dinamis dan cepat serta dengan fluktuasi kurva yang dapat naik serta turun setiap saat, pada dasarnya forex merupakan investasi mata uang asing (Valas) atau lebih dikenal dengan nama Foreign Exchange (Forex) atau spot FX dan merupakan pasar keuangan terbesar yang ada di dunia dengan volume perdagangan perharinya mencapai 19.500 triliun rupiah (Zaenal dan Silvia, 2018). Orang yang melakukan trading disebut juga treader, investasi jenis ini tergolong ber-resiko tinggi tetapi memiliki keuntunagn yang tinggi juga jika dapat membaca kurva pasar valuta asing secara profesional. Berikut ini merupakan keuntungan pada investasi pasar valuta asing:

a. Convenience : memudahkan untuk mengatur waktu dalam bertransaksi karena perdagangan dapat berjalan selama 24 jam sehari.

b. Liquidity: keuntungan hasil transaksi dapat dicairkan dengan cepat.

c. Leverage : dapat memungkinkan seorang trader yang memiliki margin deposit kecil untuk melakukan aktivitas transaksi dengan jumlah yang besar.

\section{Investasi Mata Uang Digital (Crypto Currency)}

Mata uang digital adalah teknologi dengan dasar blockchain yang digunakan sebagai mata unag digital, mata uang ini tidak memiliki bentuk fisik dan berbasis block data serta diikat oleh hash sebagai validasinya serta tidak memiliki underlaying assets serta tidak adanya kontrol dari Lembaga resmi seperti OJK. Salah satu mata uang yang terbesar nominal di crypto currency adalah Bitcoin yaitu 1 bitcoin setara dengan Rp 172,888,582.

\section{Investasi Reksadana}

Menurut Asriwahyuni (2017) reksadana adalah salah satu bentuk asset keuangan yang terdiversifikasi investasi dan merupakan masa kini yang mulai booming pada beberapa tahun ke belakang dikarenakan mudah karena hanya handel dari smartphone, dapat dimulai dari 10.000, tidak ribet karena diproses otomatis via developer aplikasi reksadana yang dipilih dan terpercaya karena telah diawasi oleh OJK, BAPEPAM \& LK (Badan Pengawas Pasar Modal dan Keuangan) dan APERD (Agen Penjual Reksa Dana) contohnya : Bibit, Tokopedia, Bukalapak. Menurut Asriwahyudi (2017) terdapat 4 unsur penting dalam pengertian reksadana yaitu:

a. Reksadana merupakan himpunan dana dari pemilik yang akan berinvestasi.

b. Diinvestasikan pada instrumen investasi yang terdapat pada efek.

c. Reksadana memiliki instrumen investasi jangka pendek dan panjang.

Dengan investasi reksadana nasabah tidak perlu khawatir terhadap kehilangan uang karena pada reksadana keuangan klien itu diletakan di Bank Kustodian sehingga jika penjual reksadana tutup maka nasabah dapat mengambil dananya di Bank Kustodian dan Bank penamupung yang ditunjuk pengelolah reksadana serta asset reksadana juga dikelola oleh manajer investasi yang ditunjuk oleh 
pengelola reksadana tersebut, keuntungan dalam reksadana ini adalah memperoleh NAV (Net Asset Value) yang diperoleh dari pergerakan harga reksadana dari hari ke hari sehingga menghasilkan selisih dari harga awal dan harga akhir reksadana tersebut yang dapat dijadikan keuntungan dalam reksadana disarankan untuk berinvestasi secara rutin setiap bulannya agar dapat mendapatkan nilai rata-rata baik turun maupun naik investasi jenis reksadana disarankan untuk jangka panjang agar hasil keuntungan yang didapat diharapkan lebih baik. Dalam investasi reksadana terdapat 4 jenis produk yang dapat dibeli yaitu:

a. Reksa Saham : Menurut Hati, Harefa (2019) yakni investasi reksadana berbentuk kumpulankumpulan saham yang dipilih pengelola reksadana berbeda dengan saham hanya dapat membeli 1 jenis saham saja Contoh saham Kimia Farma Tbk (KAEF) namun pada reksadana terdapat gabungan 30 saham korporasi terbuka dalam 1 paket reksadana investasi jenis ini memiliki resiko yang tinggi karena fluktuasi harga yang dapat terjadi setiap saat namun juga memiliki potensi return atau keuntungan yang tinggi juga.

b. Reksa Obligasi : Menurut Asriwahyuni (2017) investasi dalam reksadana yang berbentuk kumpulan obligasi (surat utang) baik korporasi dan negara investasi ini tergolong memiliki resiko moderat atau menengah dan memiliki return atau keuntungan yang berasal dari tingkat inflasi yang terjadi dan bunga deposito.

c. Reksa Pasar Uang : yakni investasi reksadana dalam bentuk campuran berupa gabungan beberapa obligasi jangka pendek (kurang dari 1 tahun saat jaduh tempo), sertifikat bank Indonesia dan deposito bank yang dipilih oleh manajer investasi reksadana tersebut.

\section{Deposito Bank}

Deposito Bank atau tabungan berjangka merupakan salah satu jenis investasi dengan cara menabung dibank tapi memiliki perbedaan dengan tabungan pada umumnya yakni uang yang ditabung pada deposito bank dapat diambil sesuai jatuh tempo yang telah disepakati biasanya setiap 1,3,6, atau 12 bulan kelebihan investasi jenis ini adalah low risk atau dengan resiko yang rendah dan dengan suku bunga yang lebih tinggi dari tabungan umumnya yakni mulai dari $2.50-6 \%$ pertahun bunga yang didapat tidak lah flat melainkan dapat berubah-ubah sesuai dengan 7-day (Reverse) Repo Rate yang merupakan kebijakan dari bank Indonesia, jika menggunakan tabungan biasa hanya mendapatkan bunga maksimal $1 \%$ pertahunnya syarat untuk membuka tabungan ini salah satunya harus memiliki NPWP serta rekening deposito.

\section{Investasi Franchise (Waralaba)}

PH Collin dalam Law Dictionary mendefinisikan franchise sebagai "license to trade using a brand name and paying a royalty for it" dan franchising sebagai "act of selling a license to tradeas a Francbisee". Dari definisi tersebut dapat ditarik kesimpulan menegnai pentingnya suatu faktor mengenai brand atau nama dagang dalam usaha waralaba atau imbalan royalti. Banyak contoh menegnai waralaba di Indonesia mulai dari kuliner seperti Kopi Janji jiwa, Kenangan sampai Starbucks maupun dibilang retail seperti Transmart, Indomart, Alfamart. Dengan adanya bisnis model seperti ini banyak pemilik brand dapat mengembangkan atau ekspansi usahanya ke tempat - tempat yang jangkauannya lebih luas.

\section{Metode Penelitian}

Penelitian ini menggunakan pendekatan kualitatif. Data dikumpulkan dengan mengadakan wawancara kepada responden sejumlah 40 orang. Selain itu dilakukan studi literatur. Menurut Zed (2014:3) studi literatur adalah serangkaian kegiatan dengan cara mengumpulkan data pustaka, membaca, mencatat dan memahami serta mengelola bahan penelitian. Pendekatan dengan metode ini dapat memberikan ilmu terkait dengan persepsi dan pengambilan keputusan milenial terhadap investasi masa depan.

\section{Hasil dan Pembahasan}

\section{Posisi Investasi}


Posisi investasi (positioning investment) adalah suatu acara untuk mengelompokkan atau mengklasifikasikan suatu hal agar lebih mudah dipahami dalam mengambil keputusan saat berinvestasi dalam posisi investasi berikut ini dikelompokkan berdasarkan 2 kriteria yaitu resiko dan penghasilan.

Tabel 1. Posisi Investasi

High Risk

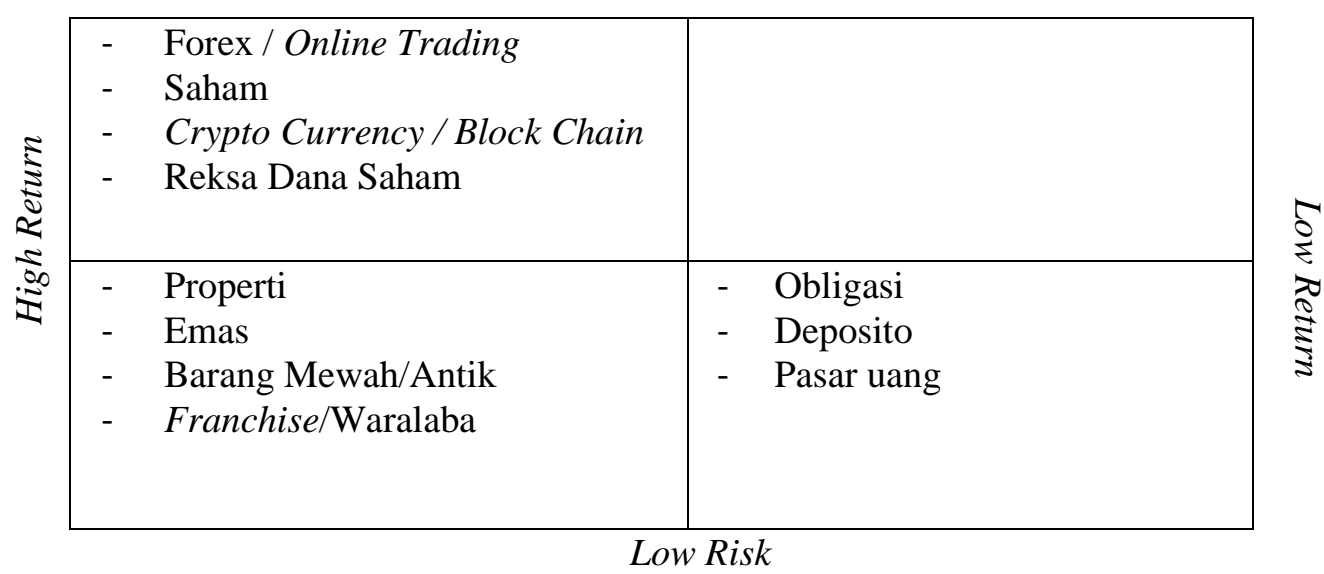

Dalam prinsip investasi secara umum semakin tinggi resiko suatu investasi maka semakin tinggi pula penghasilannya, pada dasarnya seluruh media investasi dapat menghasilkan uang dengan adanya kesabaran dan tidak terburu - buru dari ke 2 kriteria tersebut dapat mempengaruhi minat milenial terhadap investasi yang akan diambil. Menurut Pratiwi, Wahyudi, dan Siswantini (2020) keputusan berinvestasi sangat dipengaruhi oleh literasi keuangan dan pengetahuan invetasi yang dimiliki oleh seseorang dan keputusan berinvestasi tidak bergantung pada faktor demografi akan tetapi kemampuan seseorang yang dapat melihat dan memaksimalkan peluang yang ada dengan baik maka keuntungan yang akan didapatkan akan menjadi lebih maksimal. Berikut ini adalah analisis kelebihan dan kekurangan dalam berinvestasi.

Tabel 2. Kelebihan dan Kekurangan Dalam Berinvestasi

\begin{tabular}{|c|c|c|}
\hline Jenis Investasi & Kelebihan & Kekurangan \\
\hline Emas & $\begin{array}{l}\text { - Harga relatif stabil dan meningkat } \\
\text { setiap tahunnya } \\
\text { - Tersedia dalam bentuk digital dan } \\
\text { logam batangan } \\
\text { - Bebas Pajak } \\
\text { - Mudah untuk dicairkan atau dijual } \\
\text { - Dapat digadaikan }\end{array}$ & $\begin{array}{l}\text { - Harus mencari tempat yang } \\
\text { aman untuk menyimpan emas } \\
\text { fisik } \\
\text { - Rawan dengan resiko kehilangan } \\
\text { dan kejahatan } \\
\text { - Harganya cenderung melambat } \\
\text { ketika ekonomi stabil }\end{array}$ \\
\hline Saham & $\begin{array}{l}\text { - Dapat memiliki return atau keuntungan } \\
\text { lebih dari } 100 \% \text { kurang dari } 1 \text { tahun } \\
\text { contohnya saham Tesla, Amazon, } \\
\text { Zoom, Kimia Farma } \\
\text { - Dapat dijual dan dibeli dengan mudah } \\
\text { melalui smartphone } \\
\text { - Terdapat banyak saham yang dapat } \\
\text { dibeli di Bursa Efek } \\
\text { - Minimal pembelian } 1 \text { lot atau } 100 \\
\text { lembar saham } \\
\text { - Telah diawasi oleh resmi pemerintah } \\
\text { yaitu OJK }\end{array}$ & $\begin{array}{l}\text { - Fluktuasi harga saham yang } \\
\text { cepat dan dinamis membuat } \\
\text { beberapa investor frustasi } \\
\text { - Dikenakan pajak saat } \\
\text { bertransaksi saham } \\
\text { - Merupakan instrumen investasi } \\
\text { untuk jangka panjang } \\
\text { - Hanya diperdagangkan diwaktu } \\
\text { jam kerja atau waktu } \\
\text { perdagangan setempat }\end{array}$ \\
\hline
\end{tabular}




\begin{tabular}{|c|c|c|}
\hline & $\begin{array}{l}\text { - Harga saham setiap tahun cenderung } \\
\text { meningkat untuk saham blue chip, } \\
\text { IDX30 }\end{array}$ & \\
\hline Obligasi & $\begin{array}{l}\text { - Harga obligasi cenderung stabil } \\
\text { - Memiliki tingkat return lebih tinggi } \\
\text { dari pada obligasi dan pasar uang } \\
\text { - Tersedia obligasi jangka panjang dan } \\
\text { pendek }\end{array}$ & - Setiap transaksi dikenakan pajak \\
\hline Properti & $\begin{array}{l}\text { - Dapat dijadikan passive income } \\
\text { - Harga properti pada umumnya akan } \\
\text { meningkat setiap tahun } \\
\text { - Dapat digunakan oleh pemilik }\end{array}$ & $\begin{array}{l}\text { - Membutukan biaya yang tidak } \\
\text { sedikit } \\
\text { - Membutuhkan biaya renovasi } \\
\text { jika berbentuk bangunan }\end{array}$ \\
\hline Cryptocurency & $\begin{array}{l}\text { - Tidak ada pengawasan dari otoritas } \\
\text { maupun pemerintah negara manapun } \\
\text { karena berbasis block chain } \\
\text { - Dapat bertransaksi lintas negara dan } \\
\text { benua dengan cepat tanpa biaya } \\
\text { administrasi bank } \\
\text { - Semua transaksi tercatat otomatis dan } \\
\text { terbuka } \\
\text { - Berpeluang menjadi minner } \\
\text { - Jumlahnya terbatas sehingga hukum } \\
\text { permintaan berlaku } \\
\text { - Terdapat banyak macam crypto yang } \\
\text { dapat dipilih. } \\
\text { - Transaksi dapat dilakukan selama } 24 \\
\text { jam } \\
\end{array}$ & $\begin{array}{l}\text { - } \text { Fluktuasi harga sangat dinamis } \\
\text { - Merupakan mata uang yang } \\
\text { tidak resmi dalam suatu negara } \\
\text { - Mengancam peredaran uang } \\
\text { kartal } \\
\text { - Tidak ada pengawasan khusus } \\
\text { dari pemerintah }\end{array}$ \\
\hline $\begin{array}{l}\text { Tranding } \\
\text { Forex }\end{array}$ & $\begin{array}{l}\text { - Dapat memainkan momentum } \\
\text { fluktuasi harga yang dinamis dalam } \\
\text { mengambil untung } \\
\text { - Dapat dilakukan } 24 \text { jam } \\
\text { - Dapat dijadikan freelance }\end{array}$ & $\begin{array}{l}\text { - Sulit membaca pasar karena } \\
\text { fluktuasi yang dinamis } \\
\text { - Banyak orang merugi karena } \\
\text { adanya fluktuasi yang dinamis } \\
\text { dan penipuan }\end{array}$ \\
\hline Reksadana & $\begin{array}{l}\text { - Dapat dibeli dengan mudah } \\
\text { - Dapat memulai investasi dari sepuluh } \\
\text { ribu rupiah } \\
\text { - Return yang ditawarkan cukup } \\
\text { bervariasi sebanding dengan resiko } \\
\text { yang dihadapi } \\
\text { - Telah diawasi oleh OJK } \\
\text { - Dapat memilih instrumen investasi } \\
\text { mulai dari resiko rendah, moderat } \\
\text { sampai tinggi } \\
\text { - Adanya reksadana syariah } \\
\end{array}$ & $\begin{array}{l}\text { - Aktivitas dilakukan hanya pada } \\
\text { jam kerja perdagangan }\end{array}$ \\
\hline Franchise & $\begin{array}{l}\text { - } \text { Margin yang menggiurkan } \\
\text { - Tidak perlu membangun branding } \\
\text { - Tidak perlu membuat produk } \\
\text { - Tersedia paket franchise } \\
\text { - Dapat membeli usaha yang sudah } \\
\text { dikenal oleh masyarakat luas } \\
\end{array}$ & $\begin{array}{l}\text { - Memerlukan biaya yang besar } \\
\text { untuk membeli franchise } \\
\text { - Terikat dengan pemilik merek } \\
\text { - Tidak bisa merubah konsep } \\
\text { usaha yang telah ada }\end{array}$ \\
\hline Deposito & $\begin{array}{l}\text { - Memiliki bunga lebih besar dari pada } \\
\text { tabungan biasa maks. } 6 \% \text { per tahun } \\
\text { - Dapat dijadikan tabungan jangka }\end{array}$ & $\begin{array}{l}\text { - Minimum deposito yang ada } \\
\text { dimulai dari sepuluh juta rupiah } \\
\text { - } \text { Bunga berubah-ubah } \\
\end{array}$ \\
\hline
\end{tabular}




\begin{tabular}{|l|l|l|}
\hline & panjang & $\bullet \begin{array}{l}\text { Hanya dapat ditarik sesuai } \\
\text { jangka waktu yang ditentukan } \\
\text { (tabungan berjangka) }\end{array}$ \\
\hline
\end{tabular}

Pada musim pandemi saat ini banyak masyarakat dan kaum milenial yang menghemat pengeluarannya dan memilih untuk menabung (safe money) atau menginvestasikan uang nya ke instrumen investasi yang ada. Seperti yang kita ketahui bahwa investasi dalam bentuk emas dan obligasi masih menjadi primadona bagi sebagian milenial dikarenakan resiko yang rendah dan harga yang cenderung stabil serta emas sedang jaya jayanya pada saat pandemi ini. Perlu diketahui bahwa pada saat pandemi ini merupakan momentum agar milenial dapat menginvestasikan uang nya ke dalam saham karena hampir semua saham yang terdaftar dibursa efek menyentuh titik terdalamnya. Berdasarkan penelitian yang dilakukan di Politeknik Negeri Batam oleh Hati dan Harefa (2019) menyimpulkan bahwa pengetahuan mengenai pasar modal, preferensi resiko dapat mempengaruhi minat berinvestasi. Berdasarkan data Kustodian Sentral Efek Indonesia (KSEI) (2019) per 27 Desember 2019, jumlah single investor identification (SID) didominasi oleh milenial (di bawah 30 tahun) dengan komposisi 44,62 persen dan total aset Rp12,42 triliun dan berdasarkan data KSEI (2020) single investor identification (SID) masih didominasi oleh milenial dan tumbuh sebesar 44\% YoY (Maret 2020) dan total asset tercatat turun sebesar -22\% YoY serta persebaran investor domestik masih didominasi oleh DKI Jakarta dan pulau Jawa sebesar 71,46\% di urutan pertama, di urutan kedua oleh pulau Sumatera sebesar 15,52\%, pulau Kalimantan di posisi ketiga sebesar 4,93\%, pulau Bali, NTT, dan NTB sebesar sebesar 3,21\%, pulau Sulawesi sebesar 3,61\%, dan pulau Maluku dan Papua sebesar $1,26 \%$.

Dari hasil penelitian, diuraikan karakter dari responden internal terhadap persepsi dan pengambilan keputusan dalam berinvestasi. Usia responden terbanyak (40 orang) pada usia 21-25 tahun dan dengan jenis kelamin terbanyak pria (25 orang) dengan pekerjaan paling banyak sebagai karyawan swasta (18 orang). Adapun hasil temuan pada persepsi dan pengambilan keputusan milenial terhadap instrumen investasi masa depan dapat dilihat sebagai berikut:

\section{Jenis Kelamin}

Menurut Ermawati, Khotimah dan Nindyasari (2019) dalam penelitiannya menunjukan faktor jenis kelamin tidak mampu mempengaruhi keputusan berinvestasi namun baik laki-laki atau perempuan dalam memilih keputusan investasi itu berdasarkan atas pengalaman yang ada pada masing-masing orang, akan tetapi perempuan lebih bisa akurat dan berhati-hati dalam mengambil keputusan dibandingkan laki-laki.

Tabel 3. Jenis Kelamin Responden

\begin{tabular}{|c|c|c|c|}
\hline \multirow{2}{*}{ Deskripsi } & Keterangan & Total & Presentase \\
\hline \multirow{2}{*}{ Jenis Kelamin } & Pria & 25 & $63 \%$ \\
\cline { 2 - 4 } & Wanita & 15 & $38 \%$ \\
\hline \multicolumn{2}{|c|}{ Total } & 40 & $100 \%$ \\
\hline
\end{tabular}

2. Usia

Dalam berfikir dan melakukan pekerjaan secara fisik umur sangat berpengaruh terhadap kemampuan seseorang. Karena dari fakor fisik seseorang semakin tua maka semakin berkurang produktifitas kerjanya, begitu juga sebaliknya seseorang yang masih lebih muda fisiknya pun juga kuat untuk melakukan aktifitas bekerja secara fisik dan mental. Begitu juga dalam mengambil keputusan orang yang lebih tua pada dasarnya memiliki pengalaman lebih dan dapat mengambil keputusan akan berinvestasi lebih matang, dapat dilihat dari tabel 4 sebanyak 50\% dari responden yang berumur 21-25 tahun (20 orang) dari total 40 responden yang ada. 
Tabel 4. Usia Responden

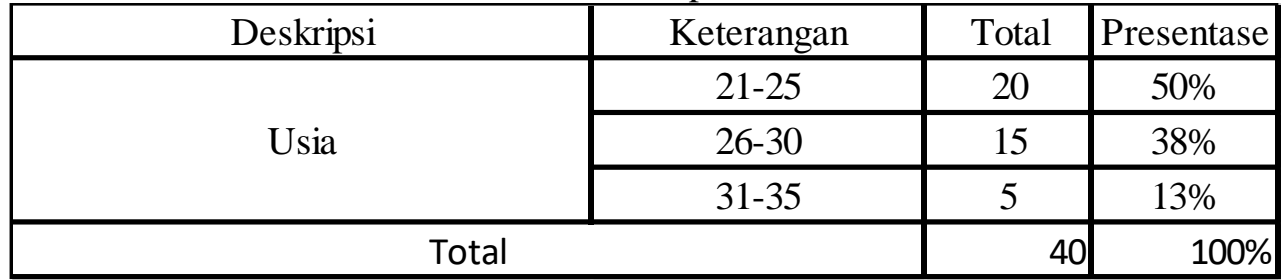

3. Pendidikan Terakhir

Dalam peningkatan sumber daya manusia dan pengetahuan serta keahlian seseorang pendidikan adalah hal yang sangat penting. Dengan jenjang pendidikan yang cukup serta tinggi dapat menjadi bekal bagi seseorang agar dapat memperoleh kesuksesan serta dapat mengubah pola pikir dan hidup untuk menjadi lebih berkembang dan maju. Pada tabel 5 menunjukan pendidikan terakhir yang dimiliki oleh responden terbanyak adalah sekolah menengah atas atau kejuruan (SMA/K) dengan 32 orang responden dan diikuti sarjana (S1/D3) sebanyak 8 orang responden. Hal itu menunjukan mereka sadar dengan pentingnya pendidikan, semakin tinggi pendidikan yang dimiliki seseorang maka semakin luas baik juga pola berfikir seseorang serta pengetahuan yang mempuni sehingga dapaat berpengaruh dalam proses pengambilan keputusan terhadap investasi yang akan dimiliki oleh seseorang.

Tabel 5. Pendidikan Terakhir Responden

\begin{tabular}{|c|c|c|c|}
\hline Deskripsi & Keterangan & Total & Presentase \\
\hline \multirow{4}{*}{ Pendidikan terakhir } & SD & & $0 \%$ \\
\cline { 2 - 4 } & SMP & & $0 \%$ \\
\cline { 2 - 4 } & SMA/K & 32 & $80 \%$ \\
\cline { 2 - 4 } & S1/D3 & 8 & $20 \%$ \\
\cline { 2 - 4 } & S2 & & $0 \%$ \\
\cline { 2 - 4 } & Lainnya & & $0 \%$ \\
\hline \multicolumn{2}{|c|}{ Total } & 40 & $100 \%$ \\
\hline
\end{tabular}

4. Pekerjaan

Jenis pekerjaan responden dapat dilihat di tabel 6. Semakin bagus pekerjaan yang dimiliki seseorang maka semakin baik juga pendapatan yang akan diperolehnya dari tabel 6 dapat dilihat bahwa sebagian besar responden bekerja sebagai karyawan swasta (18 orang) diikuti oleh wirausaha (10 orang), lainnya (7 orang) dan buruh (5 orang). Dengan semakin baiknya pendapatan yang diperoleh responden maka pada dasarnya responden dapat mengambil keputusan dengan menginvestasikan persentase gajinya untuk investasi jangka panjang dengan harapan mendapatkan keuntungan di masa mendatang.

Tabel 6. Pendidikan Terakhir Responden

\begin{tabular}{|c|c|c|c|}
\hline & Keterangan & Total & Presentase \\
\hline \multirow{3}{*}{ Deskripsi } & Wirausaha & 10 & $25 \%$ \\
\cline { 2 - 4 } & Karyawan Swasta & 18 & $45 \%$ \\
\cline { 2 - 4 } & Buruh & 5 & $13 \%$ \\
\cline { 2 - 4 } & Lainnya & 7 & $18 \%$ \\
\hline \multicolumn{2}{|c|}{ Total } & 40 & $100 \%$ \\
\hline
\end{tabular}

5. Penghasilan Perbulan

Pada tabel 7 mengenai penghasilan yang diperoleh responden perbulannya, sesuai dengan wawancara yang telah dilakukan yang menampilkan bahwa Sebagian besar responden (58\% / 23 
orang) memiliki penghasilan perbulan sebesar Rp. 3.100 .000 - 5000.000 perbulannya. Dengan hal tersebut responden dapat mengambil keputusan dalam memberbesar nominal dana investasinya yang diharapkan memiliki peluang keuntungan yang lebih besar di masa mendatang.

Tabel 7. Penghasilan Per Bulan Responden

\begin{tabular}{|c|c|c|c|}
\hline Deskripsi & Keterangan & Total & Presentase \\
\hline \multirow{4}{*}{ Penghasilan Per bulan } & $0-1000.000$ & 4 & $10 \%$ \\
\cline { 2 - 4 } & $1.100 .000-3.000 .000$ & 10 & $25 \%$ \\
\cline { 2 - 4 } & $3.100 .000-5000.000$ & 23 & $58 \%$ \\
\cline { 2 - 4 } & $5.100-10.000 .000$ & 3 & $8 \%$ \\
\cline { 2 - 4 } & $>10.000 .000$ & & $0 \%$ \\
\hline Total & 40 & $100 \%$ \\
\hline
\end{tabular}

Berikut ini adalah respon dari responden atas pertanyaan yang diberikan tentang persepsi dan pengambilan keputusan milenial terhadap instrumen investasi masa depan.

1. Pengetahuan dan Pengalaman Investasi

Dari data tabel 8 dapat dilihat bahwa responden dominan (35 orang dari 40 total orang) memiliki bekal pengetahuan serta ilmu akan investasi karena sangat berpengaruh dalam memilih keputusan dalam berinvestasi. Dengan pengetahuan dan literatur investasi yang baik diharapkan responden dapat mensortir investasi yang akan ditanamkan modal. Dapat dilihat juga pada tabel menunjukan bahwa responden telah memiliki pengalaman tersendiri dari investasi sehingga diharapkan dapat memutuskan pilihan berinvestasi dengan tepat pengalaman sangat penting bagi keputusan berinvestasi karena dengan pengalaman yang ada kita dapat menetahui mana investasi yang responsif dan menguntungkan serta sebaliknya.

Tabel 8. Pengetahuan dan Pengalaman Investasi

\begin{tabular}{|c|c|c|c|}
\hline Deskripsi & Keterangan & Total & Presentase \\
\hline $\begin{array}{c}\text { Mengetahui tentang investasi dan } \\
\text { pasar modal }\end{array}$ & Ya & 35 & $88 \%$ \\
\cline { 2 - 4 } & Tidak & 5 & $13 \%$ \\
\hline \multicolumn{2}{|c|}{ Total } & 40 & $100 \%$ \\
\hline \multicolumn{2}{|c|}{} & & \\
\hline Deskripsi & Keterangan & Total & Presentase \\
\hline \multirow{2}{*}{ Memiliki pengalaman berinvestasi } & Ya & 25 & $63 \%$ \\
\cline { 2 - 4 } & Tidak & 15 & $38 \%$ \\
\hline Total & 40 & $100 \%$ \\
\hline
\end{tabular}

2. Persepsi Responden Terhadap Investasi Saat Ini

Pada data tabel 7 menunjukan bahwa responden dominan memilih media investasi berupa properti yang menurutnya paling menguntungkan saat ini sebesar 25\% (10 orang) dan diikuti oleh deposito $18 \%$ ( 7 orang) pada kedua media investasi ini memiliki sifat yang memiliki resiko yang rendah (low risk) dan bersifat jangka panjang (long term) serta memiliki keuntungan yang stabil dan cenderung meningkat dari tahun ke tahun. Pada dasarnya keputusan berinvestasi ditentukan dari masing-masing sikap dan pandangan individu terhadap media investasi yang ada. 
Tabel 9. Persepsi Responden Terhadap Investasi Saat Ini

\begin{tabular}{|c|c|c|c|}
\hline \multicolumn{1}{|c|}{ Deskripsi } & Keterangan & Total & Presentase \\
\hline \multirow{4}{*}{$\begin{array}{c}\text { Investasi yang menurut anda yang } \\
\text { paling menguntungkan saat ini }\end{array}$} & Emas & 5 & $13 \%$ \\
\cline { 2 - 4 } & Saham & 5 & $13 \%$ \\
\cline { 2 - 4 } & Obligasi & & $0 \%$ \\
\cline { 2 - 4 } & Properti & 10 & $25 \%$ \\
\cline { 2 - 4 } & Cryptocurency & & $0 \%$ \\
\cline { 2 - 4 } & Forex & 2 & $5 \%$ \\
\cline { 2 - 4 } & Reksadana & 6 & $15 \%$ \\
\cline { 2 - 4 } & Franchise & 5 & $13 \%$ \\
\hline & Deposito & 7 & $18 \%$ \\
\hline Total & & 40 & $100 \%$ \\
\hline
\end{tabular}

3. Media Investasi Yang Dimiliki

Pada tabel 10 menunjukan data bahwa deposito menjadi investasi yang paling banyak dimiliki oleh responden (14 orang) diikuti properti (12 orang), reksadana (8 orang) dan saham sebanyak (6 orang) pada data diatas dapat diamati bahwa responden cenderung memiliki sifat berinvestasi yaitu low risk low return artinya memiliki resiko dan keuntungan yang relatif rendah.

Tabel 10. Media Investasi Yang Dimiliki

\begin{tabular}{|c|c|c|c|}
\hline Deskripsi & Keterangan & Total & Presentase \\
\hline \multirow{4}{*}{ Investasi yang telah dimiliki } & Emas & & $0 \%$ \\
\cline { 2 - 4 } & Saham & 6 & $15 \%$ \\
\cline { 2 - 4 } & Obligasi & & $0 \%$ \\
\cline { 2 - 4 } & Properti & 12 & $30 \%$ \\
\cline { 2 - 4 } & Cryptocurency & & $0 \%$ \\
\cline { 2 - 4 } & Forex & & $0 \%$ \\
\cline { 2 - 4 } & Reksadana & 8 & $20 \%$ \\
\cline { 2 - 4 } & Franchise & & $0 \%$ \\
\cline { 2 - 4 } & Deposito & 14 & $35 \%$ \\
\hline Total & & 40 & $100 \%$ \\
\hline
\end{tabular}

4. Tujuan Berinvestasi

Dilihat dari data menunjukan bahwa tujuan investasi bagi responden Sebagian besar untuk mendapatkan keuntungan sebanyak 45\% (18 orang) diikuti untuk tabungan masa depan (15 orang) dan dana darurat (7 orang). Tujuan dari investasi ini merasal dari masing-masing indivindu untuk mengarahkan fungsi dari dana investasi tersebut.

Tabel 11. Tujuan Berinvestasi

\begin{tabular}{|l|c|c|c|}
\hline \multirow{2}{*}{ Tujuan dari investasi } & Tabungan masa depan & 15 & $38 \%$ \\
\cline { 2 - 4 } & $\begin{array}{c}\text { mendapatkan } \\
\text { keuntungan }\end{array}$ & 18 & $45 \%$ \\
\cline { 2 - 4 } & Dana darurat & 7 & $18 \%$ \\
\hline
\end{tabular}

5. Hal Yang Penting Dalam Mendorong Minat Berinvestasi

Dari data pada tabel 12 dapat dilihat bahwa Sebagian besar responden berpendapat bahwa faktor keamanan (15 orang) menjadi prioritas dalam berinvestasi karena dengan adanya jaminan 
keamanan atas uang yang diinvestasikan dapat membuat investor percaya dan tertarik untuk berinvestasi. Menurut Triyanto (2018) "keamanan dan kepastian hukum merupakan kunci utama dalam berinvestasi". Kemudian faktor keuntungan (10 orang) yang merupakan harapan setiap investor dalam berinvestasi kemudian diikuti oleh faktor kepastian (8 orang) dan faktor kemudahan (7 orang).

Tabel 12. Hal Yang Penting Dalam Mendorong Minat Berinvestasi

\begin{tabular}{|c|c|c|c|}
\hline Deskripsi & Keterangan & Total & Presentase \\
\hline \multirow{4}{*}{\begin{tabular}{c} 
Hal yang penting dalam mendorong $\begin{array}{c}\text { meamanan } \\
\text { minat berinvestasi }\end{array}$ \\
\cline { 2 - 4 }
\end{tabular}} & Kepastian & 15 & $38 \%$ \\
\cline { 2 - 4 } & Kemudahan & 7 & $20 \%$ \\
\cline { 2 - 4 } & Keuntungan & 10 & $25 \%$ \\
\hline \multicolumn{2}{|c|}{ Total } & 40 & $100 \%$ \\
\hline
\end{tabular}

6. Pengaruh Persepsi dan Keputusan Dalam Berinvestasi

Pada tabel 13 data dari responden menunjukan bahwa persepsi dan keputusan akan berinvestasi dominan dipengaruhi diri sendiri sebesar 45\% (18 orang) kemudian Teman yang memberikan pengetahuan baru atau saran 25\% (10 orang), keluarga atau kerabat yang memberikan masukan atau motivasi 20\% (8 orang) serta lainnya 10\% (4 orang). Dalam mengambil keputusan berinvestasi kita dapat mencari referensi dari orang orang disekitar kita baik yang pengalaman maupun yang belum agar kita mendapatkan wawasan dan pengetahuan dalam mempertimbangkan keputusan yang akan diambil.

Tabel 13. Pengaruh Persepsi dan Keputusan Dalam Berinvestasi

\begin{tabular}{|c|c|c|c|}
\hline Deskripsi & Keterangan & Total & Presentase \\
\hline \multirow{4}{*}{$\begin{array}{c}\text { Siapa yang mempengaruhi presepsi } \\
\text { dan keputusan anda dalam } \\
\text { berinvestasi }\end{array}$} & Diri Sendiri & 18 & $45 \%$ \\
\hline & Keluarga & 8 & $20 \%$ \\
\hline & Teman & 10 & $25 \%$ \\
\hline & Lainnya & 4 & $10 \%$ \\
\hline \multicolumn{2}{|l|}{ Total } & 40 & $100 \%$ \\
\hline
\end{tabular}

\section{Kesimpulan}

Berdasarkan hasil studi dengan wawancara diperoleh kesimpulan bahwa pengetahuan dan pengalaman tentang investasi berpengaruh terhadap keputusan berinvestasi. Sebagian besar responden menginvestasikan uang nya pada media investasi yang memiliki sifat jangka panjang dan resiko yang kecil. Sementara keamanan menjadi prioritas responden saat mengambil keputusan dalam berinvestasi. Orang yang dapat mempengaruhi keputusan berinvestasi adalah motivasi dari diri sendiri. Walaupun secara bersamaan pengetahuan, pengalaman, resiko investasi dan diri sendiri berpengaruh terhadap keputusan berinvestasi.

\section{Daftar Pustaka}

Tandio, T., Widanaputra. (2016). Pengaruh Pelatihan Pasar Modal, Return, Persepsi Risiko, Gender dan Kemajuan Teknologi Pada Minat Investasi Mahasiswa. E-Jurnal Akuntansi Universitas Udayana, 16(3), 2316-2341

Rianto R.D., Etty, S. (2019). Perilaku Organisasi : Konsep Dan Implementasi. Jakarta : PT Filda Fikrindo.

Hidayat, L., Muktiadji, N., Supriadi, Y. (2019). Peluang Investasi Emas Jangka Panjang Melalui Produk Pembiayaan Bsm Cicil Emas (Studi Pada Bank Syariah Mandiri K.C. Purwokerto) Jurnal Analisis Sistem Pendidikan Tinggi, 3(2), 64-65

Fauziah, A., Surya, M.E. (2016). Pengaruh Pengetahuan Investasi Terhadap Minat Mahasiswa Berinvestasi di Galeri Investasi Perguruan Tinggi. Islamadina, 16(1), 56-59 
Sebastian, Y., Dkk (2016). Generasi Langgas Millenials Indonesia. Jakarta : Gagas Media.

Sanicola, L. (2017, Februari 13). What is FinTech? [News]. Diakses dari https://www.huffpost.com/entry/what-is-fintech_b_58a20d80e4b0cd37efcfebaa

Bisnis.com. (2017). "Hasil Riset: Generasi Milenial Paling Suka Investasi Emas"[News]. Diakses dari https://gaya.tempo.co/read/1037759/hasil-riset-generasi-milenial-paling-suka-investasi-emas

Trisnatio, Y. A. (2017). Pengaruh Ekspektasi Return, Persepsi Terhadap Risiko dan Self Efficacy Terhadap Minat Investasi Saham Mahasiswa. Fakultas Ekonomi Universitas Negeri Yogyakarta, (1), 6-15.

Tandelilin, E. (2012). Analisis Investasi dan Manajemen Portofolio. Teori dan Aplikasi. Yogyakarta: BPFE

Munawaroh, A., Utomo, C., (2017) Analisa Investasi The Akavia Indekost Residences Ngaliyan Semarang. Jurnal Teknik ITS. 6(1), D68-69

Widjaja, G. (2002). Lisensi Atau Waralaba Suatu Panduan Praktis. Jakarta: PT Raja Grafindo Persada.

Sitohang, S. N. (2017). Pengaruh Pengetahuan Investasi Terhadap Minat Mahasiswa Berinvestasi di Pasar Modal (FEB Universitas Sumatera Utara).

Prayoga I,B,B. 2018. Teknologi Blockchain Cryptocurrency Di Era Revolusi Digital. Universitas Pendidikan Ganesha. 29(9): 173-177

Asriwahyudi I,G,A,P. (2017). Pengaruh Ukuran Dan Umur Pada Kinerja Reksa Dana Saham Di Indonesia. E-Jurnal Akuntansi Universitas Udayana. 21(2), 1461-1469

Asep Z,A., Elsa S,N,A. 2018. Teknologi Blockchain Cryptocurrency Di Era Revolusi Digital. Universitas Pendidikan Ganesha. 17(1): 73-175

Aren, S., \& Aydemir, S., D. (2015). The Moderation of Financial Literacy on the Relationship Between Individual Factors and Risky Investment Intention. International Business Research, $8(6), 17-28$.

Hati, S,W., Harefa, W,S. (2019). "Analisis Faktor-Faktor Yang Mempengaruhi Minat Berinvestasi Di Pasar Modal Bagi Generasi Milenial (Studi Pada Mahasiswi Jurusan Manajemen Bisnis Politeknik Negeri Batam)". Journal of Business Administration 3(2), 294.

Nadia G, P., Wahyudi, T, S. (2020). Analisis Keputusan Investasi Pasar Modal pada Generasi Milennial Uniersitas Pembangunan Nasional veteran Jakarta, 563.

Sim, T, Mr. 2019. Mengapa Kita Harus Investasi Saham. Edisi Pertama. Jakarta: PT. Mirae Asset Sekuritas Indonesia.

KSEI. 2020. KSEI NEWS Edisi 1. Jakarta: PT. Kustodian Sentral Efek Indonesia, 9-11. Diakses dari:

https://www.ksei.co.id/files/uploads/fokuss_bulletins/fokuss_file/idid/61_edisi_1_20200604102828.pdf

Triyanto. 2018. Aspek Keamanan Alasan Utama Investor Untuk Berinvestasi. Diakses dari: https://www.babelprov.go.id/content/aspek-keamanan-alasan-utama-investor-untuk-berinvestasi

Ermawati, N., Khotimah, T., Nindyasari, R. (2019). Faktor-Faktor Yang Mempengaruhi Usaha Mikro Kecil Menengah (UMKM) Dalam Pengambilan Keputusan Investasi Studi Kasus Pada UMKM Batik Tulis Lasem. Universitas Muria Kudus. ISBN: 978-979-3649-99-3. Hal 551.

\section{*Email korespondensi:}

yosua.dragz@gmail.com 